\title{
INFANT AND EARLY CHILDHOOD DEATH RATES OVER THE LAST HUNDRED YEARS IN THE NEGRO POPULATION OF ANTIGUA, BRITISH WEST INDIES
}

\author{
BY \\ K. H. UTTLEY \\ Antigua, British West Indies
}

Antigua, an island of 108 square miles in the West Indies, has a population mainly of pure African descent, with less than 10 per cent. of mixed blood. In this paper all data about the small white section of the community have been excluded. The economy is an agricultural one, but the diet has always been very unbalanced, especially in the case of infants, who are given an excess of carbohydrates almost from birth with little protein. Periodic droughts every 3 or 4 years result in an increased incidence of malnutrition in the young which is a major factor in reducing the child's resistance to the main killing diseases at ages under 5 years-gastro-enteritis and respiratory infections. The standard of living is low, and there is great ignorance about the most elementary matters of family and home life, hygiene and sanitation, made worse by the general fecklessness of the people. Fortunately, overcrowding is not a serious problem. Marriage is the exception, 66 per cent. of all births being illegitimate. The father is often not an important element in family life; he may or may not live with it or contribute to its expenses. With such a family structure the grandmother is the most important factor; the mother often goes out to work on the land 4 to 6 weeks after the birth of her child.

\section{Registration of Births and Deaths}

In 1856, compulsory birth, stillbirth, and death registration was introduced. As regards deaths, no dead body could be buried without a burial order, which in turn could not be issued without a doctor's or coroner's certificate of the cause of death. As regards births, a series of ordinances culminated in the Midwives Ordinance of 1880 which provided a more than adequate supply of midwives for the whole island, i.e. one for every 1,200 persons. Further factors influencing the accuracy and completeness of birth and death registration over the century are (a) a good sufficiency of physicians trained in the United Kingdom or Canada, and (b) the fact that the island is a small one with good internal communications.

Since 1851 there have been eight censuses in Antigua: in 1861, 1871, 1881, 1891, 1901 (totals of the sexes only), 1911, 1921, and 1946. Probably a certain proportion of the very young escaped enumeration at the censuses, but apart from this it is likely that the totals for the two sexes were fairly accurate. However, as in all tropical and backward communities where people have only vague ideas as to their date of birth, there are bound to be many errors as regards the ages as stated to the enumerators.

\section{The Survey}

As with many of the smaller West Indian islands, the official annual returns in Antigua have been vitiated at different times by inaccuracies due to (i) failure to differentiate records of white persons from those of African descent, and (ii) failure to separate records about stillbirths from live births; indeed sometimes there was no indication whether or where stillbirths were included. With these facts in mind, the author investigated all the birth and death registers for the century 1857 to 1956 to collect accurate information about the coloured population of the island. This paper deals only with the infant and early childhood death rates; the general birth, stillbirth, death, and fertility rates are discussed elsewhere (Uttley, 1960).

Table I (overleaf) summarizes all the deaths under 5 years of age that occurred between 1857 and 1956 . The information is arranged to show:

(1) The number of deaths occurring in each age group;

(2) The death rate in each age group, under one year of age per 1,000 live births;

(3) The total number of births by sex, occurring in each decade. 
TABLE I

CENSUS POPULATIONS, BIRTHS, STILLBIRTHS, AND DEATHS IN THE FIRST 5 YEARS OF LIFE, IN ANTIGUA IN EACH DECADE 1857-66 TO 1947-56

\begin{tabular}{|c|c|c|c|c|c|c|c|c|c|c|c|c|c|c|c|c|c|c|c|c|c|c|}
\hline \multirow{3}{*}{$\begin{array}{l}\text { De- } \\
\text { cade }\end{array}$} & \multicolumn{4}{|c|}{ Census Population } & \multirow{2}{*}{\multicolumn{2}{|c|}{$\begin{array}{c}\text { Live Births } \\
\text { (decade) }\end{array}$}} & \multirow{2}{*}{\multicolumn{2}{|c|}{$\begin{array}{l}\text { Stillbirths } \\
\text { (decade) }\end{array}$}} & \multicolumn{14}{|c|}{ Deaths (decade) by Age } \\
\hline & \multicolumn{2}{|c|}{$\begin{array}{l}\text { Under } \\
1 \text { Year }\end{array}$} & \multicolumn{2}{|c|}{$\begin{array}{l}1-4 \\
\text { Years }\end{array}$} & & & & & \multicolumn{2}{|c|}{$\begin{array}{l}6 \text { Days } \\
\text { and } \\
\text { Under }\end{array}$} & \multicolumn{2}{|c|}{$\begin{array}{l}7-28 \\
\text { Days }\end{array}$} & \multicolumn{2}{|c|}{$\begin{array}{c}29 \text { Days }- \\
2 \\
\text { Months }\end{array}$} & \multicolumn{2}{|c|}{$\begin{array}{l}3-5 \\
\text { Months }\end{array}$} & \multicolumn{2}{|c|}{$\stackrel{6-11}{\text { Months }}$} & \multicolumn{2}{|c|}{$\begin{array}{c}\text { Total } \\
\text { Under } 1 \\
\text { Year }\end{array}$} & \multicolumn{2}{|c|}{$\underset{\text { Years }}{1-4}$} \\
\hline & $\mathbf{M}$ & $\mathbf{F}$ & $\mathbf{M}$ & $\mathbf{F}$ & $\mathbf{M}$ & $\mathbf{F}$ & $\mathbf{M}$ & $\mathbf{F}$ & $\mathbf{M}$ & $\mathbf{F}$ & $\mathbf{M}$ & $\mathbf{F}$ & $\mathbf{M}$ & $\mathbf{F}$ & $\mathbf{M}$ & $\mathbf{F}$ & $\mathbf{M}$ & $\mathbf{F}$ & $\mathbf{M}$ & $\mathbf{F}$ & $\mathbf{M}$ & $\mathbf{F}$ \\
\hline $\begin{array}{c}1857- \\
1866\end{array}$ & 389 & 408 & 1,476 & 1,570 & 5,780 & 5,419 & 841 & 713 & 294 & 271 & 283 & 261 & 172 & 172 & 233 & 201 & 246 & 253 & 1,228 & 1,158 & 619 & 591 \\
\hline $\begin{array}{c}1867- \\
1876\end{array}$ & 624 & 517 & 1,637 & 1,599 & 6,972 & 6,553 & 1,045 & 890 & 331 & 306 & 370 & 329 & 286 & 219 & 348 & 329 & 448 & 370 & 1,783 & 1,553 & 733 & 679 \\
\hline $\begin{array}{c}1877- \\
1886\end{array}$ & 542 & 624 & 1,440 & 1,686 & 6,650 & 6,313 & 871 & 695 & 347 & 282 & 396 & 373 & 204 & 175 & 396 & 298 & 429 & 402 & 1,772 & 1,530 & 732 & 713 \\
\hline $\begin{array}{c}1887- \\
1896\end{array}$ & 457 & 437 & 1,734 & 1,762 & 6,336 & 6,288 & 669 & 543 & 291 & 224 & 333 & 289 & 220 & 247 & 386 & 332 & 457 & 414 & 1,687 & 1,506 & 807 & 814 \\
\hline $\begin{array}{c}1897- \\
1906\end{array}$ & \multicolumn{4}{|c|}{ Not available } & 6,010 & 5,748 & 536 & 486 & 266 & 167 & 211 & 210 & 209 & 185 & 318 & 310 & 447 & 351 & 1,451 & 1,223 & 889 & 830 \\
\hline $\begin{array}{c}1907- \\
1916\end{array}$ & 399 & 442 & 1,545 & 1,544 & 5,373 & 5,173 & 548 & 432 & 181 & 156 & 165 & 135 & 180 & 168 & 255 & 228 & 351 & 328 & 1,132 & 1,015 & 625 & 693 \\
\hline $\begin{array}{c}1917- \\
1926\end{array}$ & 333 & 350 & 1,379 & 1,433 & 5,086 & 4,828 & 402 & 338 & 172 & 133 & 113 & 112 & 156 & 165 & 228 & 204 & 320 & 323 & 989 & 937 & 596 & 604 \\
\hline $\begin{array}{c}1927- \\
1936\end{array}$ & \multicolumn{4}{|c|}{ No Census } & 5,226 & 5,057 & 331 & 307 & 164 & 118 & 76 & 62 & 109 & 120 & 153 & 133 & 243 & 229 & 745 & 662 & 388 & 321 \\
\hline $\begin{array}{c}1937- \\
1946 \\
\end{array}$ & \multirow{2}{*}{692} & \multirow{2}{*}{682} & \multirow{2}{*}{2,239} & \multirow{2}{*}{2,317} & 6,460 & 6,528 & 333 & 302 & 175 & 136 & 79 & 66 & 140 & 125 & 185 & 175 & 256 & 307 & 835 & 809 & 415 & 391 \\
\hline $\begin{array}{c}1947- \\
1956\end{array}$ & & & & & 8,282 & 8,232 & 298 & 258 & 176 & 124 & 51 & 58 & 89 & 96 & 117 & 132 & 216 & 231 & 649 & 641 & 282 & 282 \\
\hline
\end{tabular}

It should be borne in mind, however, that the figures for the first decade, dealing with the years immediately after the introduction of the Births and Deaths Ordinance, may be assumed to be incomplete and may represent an understatement of the facts.

If the age groups are considered in turn, mortality in the first week of life has fallen to two-fifths of what it was a century ago; that of the age group 7 to 28 days to one-seventh; that of the neonatal group as a whole to one-quarter; and that in the other groups has fallen to between one-third and 60 per cent. In most groups the rate for males has almost always exceeded that for females in the same decade, so that the male/female neonatal mortality ratio has been above unity as is usual throughout the world.

Table II gives the usual mortality statistics for the first 5 years of life, grouped by decades over the century.

It is probably better to ignore for the present the figures for the first decade, 1857-1866.

Table II brings out the following facts:

(1) That neonatal mortality has fallen from 99 to 25 , the fall being very steady over the last 80 years;
(2) That post-neonatal mortality has fallen to 53, one-third of what it was 70 years ago, the main fall being in the last 40 years.

It is worth mentioning that the decade with the highest post-neonatal mortality, 1887-1896, coincided with a decade of severe droughts and economic depression, but the depression did not affect the decline in the neonatal mortality (which had begun a quarter of a century before), nor did it affect the other statistics in the Table for the same decade.

(3) The total infant mortality probably did not vary much for the first 40 years of the century under review, but since then it has declined to 78 , less than one-third of its former figure;

(4) The stillbirth rate, at first over 120 per 1,000 total births, has shown a very steady fall over the last 90 years to 32 ;

(5) The perinatal death rate has fallen pari passu with the stillbirth rate; at 50 per 1,000 total births it is now 30 per cent. of the figure of a century ago;

(6) The death rate at age $0-1$ year per 1,000 living at that age was around 300 for the first 50 years of the century, but rose to 357 during the years 18871896 when droughts and economic depression prevailed; since then it has fallen steadily to nearly one-third of the earlier figure; 
TABLE II

MORTALITY STATISTICS FOR THE FIRST 5 YEARS OF LIFE, BY DECADES, ANTIGUA, 1857-1956

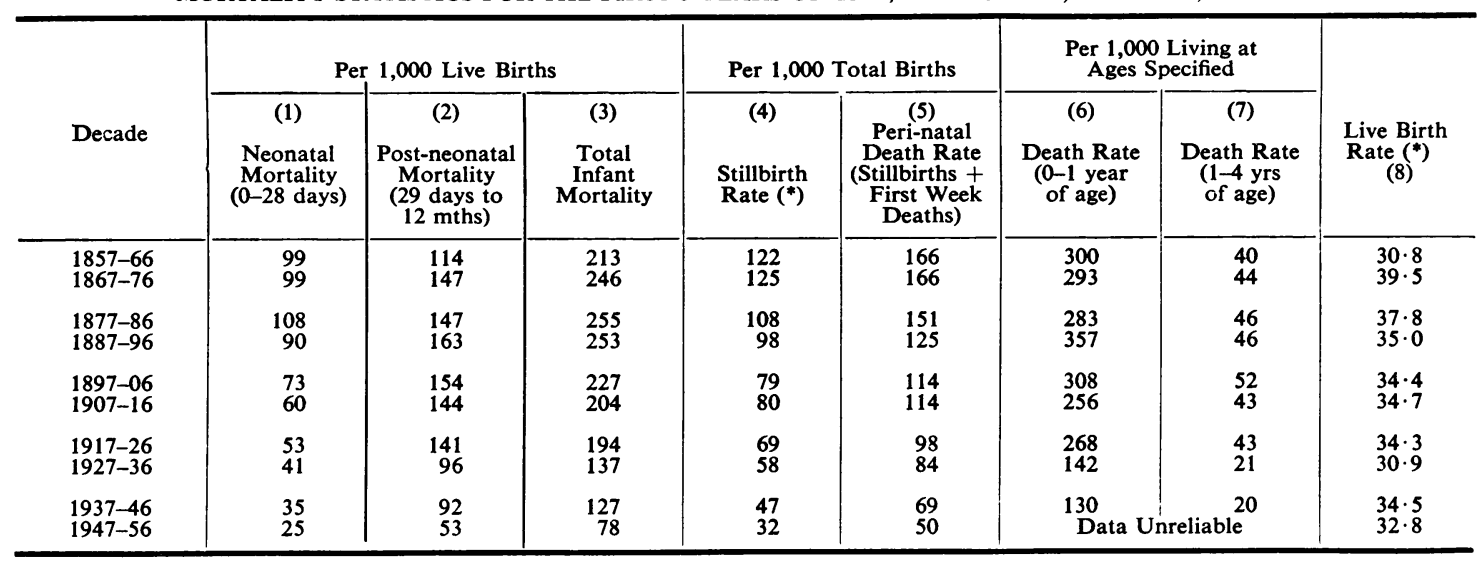

* From Uttley (1960).

(7) The corresponding death rate at age $1-4$ years showed little change until after the first world war, being between 40 and 46 , except for a rise to 52 during the years of depression. After 1926 the rate fell quickly to 21 , at which figure it has remained stationary;

(8) The live birth rate has fluctuated between $39 \cdot 5$ and $30 \cdot 8$, the average being $34 \cdot 5$. It would be premature to assume that it has yet started to fall.

It is known that the stillbirth rate in many countries is closely related to the neonatal mortality. A reference to Columns 4 and 1 in Table II confirms this in general for Antigua; though the ratio in the 19th century was somewhat lower than in the 20th, it has normally been above unity.

Over the whole period studied there has been relatively little change in the proportion of neonatal to total infant mortality in Antigua, which has remained at about 30 per cent. for the last six decades (Table III). This is in striking contrast to most highly-developed countries, where the postneonatal rate has declined very much more rapidly than the neonatal rate in this period, and where neonatal deaths as a result now contribute the larger share, about 70 per cent. of the total infant deaths.

In the tropics, where accurate death registration is the exception, deaths in infancy and early childhood are usually expressed as a percentage of all deaths. In Antigua, after the first decade of registration, the total mortality at ages under 5 years fluctuated between $32 \cdot 7$ and $42 \cdot 5$ per cent. of all
TABLE III

THE NEONATAL MORTALITY AS PERCENTAGE OF INFANT MORTALITY, BY DECADES, ANTIGUA, 1957-1958

\begin{tabular}{c|c}
\hline Decade & Percentage Neonatal Mortality \\
\hline $1857-1866$ & $46 \cdot 4$ \\
$1867-1876$ & $40 \cdot 2$ \\
$1877-1886$ & $42 \cdot 4$ \\
$1887-1896$ & $35 \cdot 6$ \\
$1897-1906$ & $32 \cdot 3$ \\
$1907-1916$ & $29 \cdot 4$ \\
$1917-1926$ & $27 \cdot 3$ \\
$1927-1936$ & $29 \cdot 9$ \\
$1937-1946$ & $27 \cdot 6$ \\
$1947-1956$ & $32 \cdot 1$ \\
\hline
\end{tabular}

deaths; deaths at age $1-4$ years varied somewhat more, but have fallen steadily from 16 per cent. in the decade 1897-1906 to 10 per cent. in the last decade.

Deaths under one year of age remained remarkably steady all the century at around 25 per cent. of all deaths, showing a slight rise in the decade 18871896, the years of economic depression and of droughts. In Europe over the last generation a marked fall has occurred in the ratio of deaths under one year to total deaths, a change which has not yet appeared in Antigua. This may be due partly to differences in the population structure in Europe and Antigua, but is also partly due to the disease pattern being different in the two localities.

A comparison of the two halves of Table IV shows that just after 1900 the neonatal mortality in Antigua was 50 per cent. higher than that in England 
and Wales, and that since then the fall has been approximately in about the same proportion.

\section{TABLE IV}

THE DECLINE IN NEONATAL AND INFANT MORTALITY RATES IN ANTIGUA (1857-1956) AND ENGLAND AND WALES, 1856-1950

\begin{tabular}{c|c|c|c|c|c}
\hline \multicolumn{3}{c|}{ Antigua } & \multicolumn{2}{c}{ England and Wales } \\
\cline { 5 - 6 } Decade & $\begin{array}{c}\text { Neonatal } \\
\text { Mortality }\end{array}$ & $\begin{array}{c}\text { Infant } \\
\text { Mortality }\end{array}$ & Years & $\begin{array}{c}\text { Neonatal } \\
\text { Mortality }\end{array}$ & $\begin{array}{c}\text { Infant } \\
\text { Mortality }\end{array}$ \\
\hline $1857-1866$ & 99 & 213 & $1856-1860$ & - & 152 \\
$1867-1876$ & 99 & 246 & $1866-1870$ & - & 157 \\
$1877-1886$ & 108 & 255 & $1876-1880$ & - & 145 \\
$1887-1896$ & 90 & 253 & $1886-1890$ & - & 145 \\
$1897-1906$ & 73 & 227 & $1896-1900$ & - & 156 \\
$1907-1916$ & 60 & 204 & $1906-1910$ & 40 & 117 \\
$1917-1926$ & 53 & 194 & $1916-1920$ & 37 & 91 \\
$1927-1936$ & 41 & 137 & $1926-1930$ & 32 & 68 \\
$1937-1946$ & 25 & 127 & $1936-1940$ & 29 & 55 \\
$1947-1956$ & 25 & 78 & $1946-1950$ & 21 & 36 \\
\hline
\end{tabular}

In the case of the infant death rate, that for Antigua has occasionally been more than 100 per cent. higher than it was in England and Wales at the same time. In the latter the fall occurred rapidly at the turn of the century before it began to fall materially in Antigua, so that, even though the fall in Antigua has been a steady one, the rate still remains more than double that for England and Wales; there is nothing to suggest that the rate of fall is slowing down.

\section{Discussion}

Infant mortality is influenced by a number of social and environmental factors, such as poverty, improper feeding, parental ignorance, illegitimacy, instability of the family structure, overcrowding, poor sanitation, and climate; many of these factors are inter-related.

Poverty is common on the island and is fundamental to the problem. With it there is in general an unsatisfactory diet, poor in protein, which must be particularly inadequate for pregnant women and young children. Coupled with poverty and poor diet is parental ignorance, prejudice, and fecklessness. Illegitimacy may be an important factor. It is true that since only a minority of mothers are married there is no associated social stigma as in Europe: nevertheless, there is a considerable economic handicap in the lack of paternal contribution to the household. The necessity to return to work within a few weeks of labour aggravates the situation by interrupting breast feeding, and there is no substitute in the form of a cheap, safe milk supply. Parental irresponsibility and ignorance lead to low standards of child care.

There is little overcrowding in Antigua, in the sense of a high density of population per acre, but considerable overcrowding within the small dwellings. This may in part account for the importance of infectious diseases as a cause of death in the early years, while poor sanitation encourages alimentary infections. The spread of syphilis is clearly aided by promiscuity and the lack of stable family patterns.

Although there has been a fall in the mortality in early life, Antigua still has a long way to go. As elsewhere in the tropics, a considerable improvement can be expected in the reduction of the contribution of infectious diseases by general sanitary measures, while a further gain can be achieved by social and economic measures leading to the better nutrition of mothers and children.

\section{SUMmaRY AND CONCLUSIONS}

Because Antigua has been very favourably placed for carrying out such an investigation, it has been possible by an inspection of all birth and death registration records, to calculate fairly accurately the death rates at various ages under 5 years of the Negro population of the island over the period of one hundred years from 1857 to 1956.

Censuses have been taken eight times in the century, all births, stillbirths, and causes of death have been recorded fairly accurately throughout the century, and there is a self-contained agricultural community of 30,000 to 50,000 persons in a small island with good internal communications, and a satisfactory supply of well-trained physicians.

Deaths of infants under one year of age have accounted for one-quarter of all deaths in most decades; those of children aged 1 to 4 years inclusive have accounted for another one-eighth. Infant mortality has fallen from a steady 250 per 1,000 in the 19th century to 78 in 1947-1956.

Over the century the neonatal mortality has remained about one-third of the total infant mortality. At the turn of the century the neonatal death rate in Antigua was $\mathbf{5 0}$ per cent. higher than that for England and Wales, a ratio that still prevails. Unlike England and Wales, post-neonatal mortality has not fallen more rapidly than neonatal mortality.

The Antigua infant death rate was 50 per cent. higher than that for England and Wales in the latter half of the 19th century and showed very little change during the period; at present it is about three 
times as high as the current figure for England and Wales because of the more rapid fall in the latter. However, the rate is still falling rapidly in Antigua.

The death rates at age $0-1$ year per 1,000 at that age was 300 or more until the turn of the century, since when it has fallen to 119 . The corresponding figure for ages 1-4 years lay between 40 and 52 until the first world war, since when it has been reduced to 20 to 21 .

Throughout the period the birth rate fell from $45 \cdot 2$ in $1867-1876$ to $33 \cdot 9$ in $1947-1956$.

The factors that have influenced the death rates in the very young in Antigua include the prevalence of gastro-intestinal and pulmonary conditions, malnutrition, the matriarchal structure of the family, poverty, ignorance, and fecklessness.

This article is one of a series by the author, assisted by a grant from the Standing Advisory Committee for Medical Research in the British Caribbean, for which he wishes to express his thanks. He also wishes to thank Mr. G. W. Roberts, Vital Statistics Officer of the West Indian Federal Government, for his helpful advice and criticism.

\section{REFERENCE}

Uttley, K. H. (1960). "The Birth, Stillbirth, Death, and Fertility Rates in the Coloured Population of Antigua, West Indies, from 1857 to 1956". Trans. roy. Soc. trop. Med. Hyg. (In the press). 